\title{
Taxonomic notes on the genus Chaenorhinum (Plantaginaceae) in Turkey
}

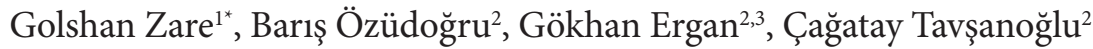 \\ ${ }^{1}$ Department of Pharmaceutical Botany, Faculty of Pharmacy, Hacettepe University, 06100, Sihiyye, Ankara, Turkey \\ ${ }^{2}$ Department of Biology, Faculty of Science, Hacettepe University, 06800, Beytepe, Ankara, Turkey \\ ${ }^{3}$ Eastern Mediterranean Research Association, 182, Yağca St., Yağca, Döşemealtı, Antalya
}

\begin{abstract}
Chaenorhinum gerense is an eastern Mediterranean species with rare distribution and a large variety in plant and seed morphology. In this study, the accuracy of the taxonomic status of this species, which was initially reported by P.H. Davis as C. rubrifolium from south eastern Turkey, is discussed and the typical representatives of C. rubrifolium were collected for the first time for Turkey from Muğla province, southwestern Anatolia. C. gerense is closely related to the C. rubrifolium, from which it differs by having a small and cream corolla with red blotch, capsule as long as or smaller 1/2-calyx teeth and triangular or rectangular blunt crest on seed. Detailed descriptions and identification keys for these two taxa are provided.
\end{abstract}

Key words: Chaenorhinum rubrifolium, Chaenorhinum gerense, Mediterranean Basin, Plantaginaceae, Turkey

\section{Introduction}

The genus Chaenorhinum (DC.) Rchb. (1828: 123) was described as a section of Linaria by De Candolle (1815:410) and then raised by Reichenbach (1828) to the generic level. The taxonomy of the genus especially C. rubrifolium (Robill. \& Castagne ex DC.) Fourr. species complex is rather problematic, because of considerable intraspecific variation, insufficient distribution data, confusing synonymies, incorrectly cited names, poorly described species and the distinction of numerous subspecies, varieties and forms (Fourreau 1869, Fernandes 1971, Speta 1980, Sutton 1988, BenedíGonzález 1991). The genus consists of ca. 20 species mainly distributed in southwest Europe, north Africa and south west Asia (Benedí and Güemes 2009). Davis (1978a) reported six species for the Flora of Turkey and then, C. semispeluncarum Yıldırım, Kit Tan, Şenol \& Pirhan and C. yildirimlii Yıldırım, Kit Tan, Şenol \& Pirhan have been described as new species (Ylldırım et al. 2010). Consequently, five (ca. 50\%) of the eight Chaenorhinum species present in Turkey are endemics. Despite the high endemism ratio and species diversity, the genus is poorly known throughout the Mediterranean Basin, and especially in Turkey.

During field studies (March 2014 and June 2016) in a study on post-fire recovery of Mediterranean pine forests in Muğla province (Turkey), some Chaenorhinum materials were collected. Comparisons with present materials in Turkish herbaria (ANK, GAZI, HUB and ISTE) and the Flora of Turkey (Davis 1978a) yielded no matching identification. Further herbarium studies and detailed micro-morphological investigations clearly showed that these materials belong to the common Mediterranean species C. rubrifolium, which was reported initially from the eastern part of Anatolia by Davis in his account (Davis 1978b). More detailed fieldwork and micro and macro-morphological investigations of the East Anatolian materials confirmed Sutton's decision (1988) to place these taxa belong in C. gerense (Stapf) Speta (1980: 27). Therefore, C. rubrifolium is introduced here as a new record for the Flora of Turkey.

\section{Materials and methods}

Fresh plant materials were collected from the field during excursions in 2014 and 2015. The specimens are deposited in Hacettepe University Herbarium (HUB). Herbarium specimens of Chaenorhinum in ANK, B, BC, E, GAZI, HUB, ISTE, MSB and W (acronyms according to Thiers 2016) were also examined. For scanning electron microscopy (SEM), dry seeds were mounted directly on stubs (Plaza et al. 2004) and coated with gold in a sputter coater prior to observation with a JEOL JSM-6490 LV scanning electron microscope.

* Corresponding author, e-mail: golshanzare@gmail.com 


\section{Results and discussion}

Chaenorhinum gerense (Stapf) Speta in Stapfia 7: 27 (1980)

Basionym: Linaria gerensis Stapf, Bull. Misc. Inform. Kew (3): 75 (1906)

Type: Persia: In rupestribus prope pagum Gere inter Abuschir et Schiras, 23.3.1842, Th. Kotschy 92, holotype K; isotypes G, G-BOIS, JE, M, P, W!.

Morphological description: Erect, slender, annual, 2.5$12(-25) \mathrm{cm}$, glandular-pubescent. Stem flexuous, simple or branched, adpressed to rocks. Basal rosette leaves elliptical to ovate, $8-12 \times 3-4 \mathrm{~mm}$, petiolate, green rarely purple below, glabrous, median cauline leaves elliptical to lanceolate, subsessile, glandular-pubescent. Raceme lax, flower patent. Pedicels ascending or patent in fruit, $5-10 \mathrm{~mm}$, as long as or longer than leaf-like bracts. Calyx lobes 4-7 mm, linear to linear-spathulate, obtuse, usually patent or recurved. Corolla creamy, suffused with red or pink batch on the upper side, 5-7 (9) mm (included spur); spur tapering, 1.5-2 mm, subacute. Capsule spherical, $2-3 \mathrm{~mm}, 2-3 \times$ as short as calyx teeth. Seed ovoid-ellipsoid, small, $0.30-0.50 \times 0.30-0.35$ $\mathrm{mm}$, dark brown, with prominent longitudinal crest, discontinues, triangular or rectangular blunt and obtuse apex, testa of the intercostal spaces covered by papilla (Figs. 1,2).

Flowering and fruiting time: April-May.

Habitat: Crevices of limestone rocks and walls from 350 to $1200 \mathrm{~m}$ altitude.

General distribution: Eastern Mediterranean, Cyprus, Iran, Iraq, Pakistan, Turkey.

Examined specimens: Turkey: C8 Mardin: c. 11-13 km from Mardin to Savur, May 1957, Davis 28529 (E!), $4 \mathrm{~km}$

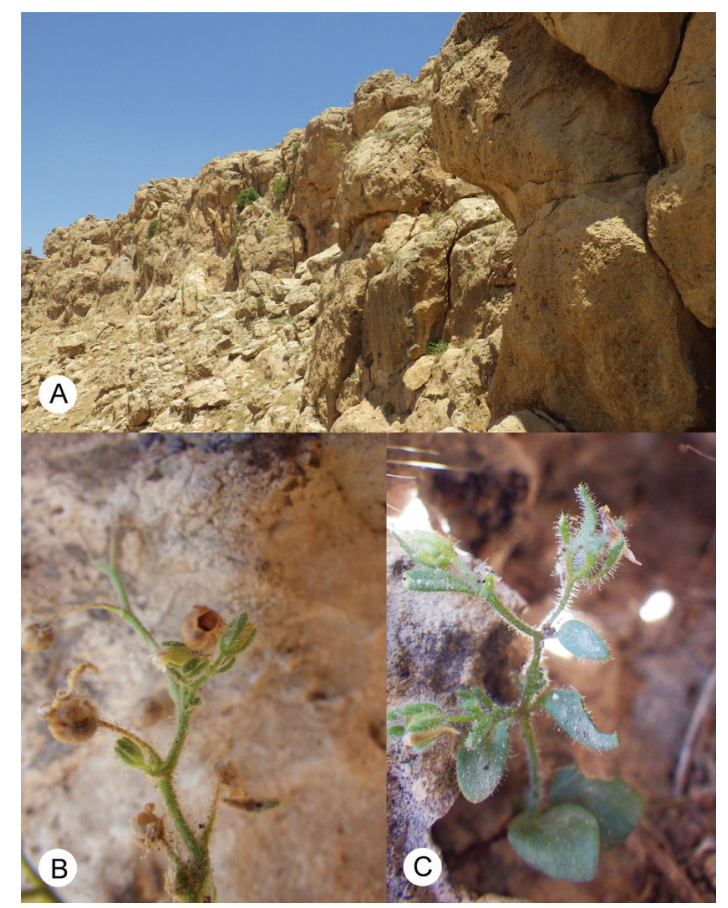

Fig. 1. Chaenorhinum gerense: A) habitat; B) a general appearance; C) fruits and flowers (GZ1093).
E. of Mardin, 1200 m, 25 May 1957, Davis 28577 (E!), E of Mardin, Eskikale village, limestone rocks, 1114 m, 37¹8'29" N 4045'53" E, 06 June 2015, G. Zare \& G. Ergan, GZ1093 (HUB!), C9 Mardin: Cizre, 350 m, Walls of mosque, 09 May 1966, Davis 42705 (E!).

Chaenorhinum rubrifolium (Robill. \& Castagne ex DC.) Fourr. in Ann. Soc. Linn. Lyon nov. ser. 17: 127 (1869)

Basionym: Linaria rubrifolia Robill. \& Castagne ex DC., Fl. Fr. 5: 410 (1815)

Lectotype: Described from S. France, Cette plante croît sur les collines rocailleuses des environs de Marseille, notamment près le fort de N.-D.-de-la-Garde du côté de la mer [lectotype designated by C. Benedí in Collect. Bot. (Barcelona) 20: 72 (1991): G-DC]

Morphological description: Erect, slender, annual, 4-22 $\mathrm{cm}$ high, glandular-pubescent often tinged purple. Stem flexuous, simple or branched. Basal leaves broadly obovate or spathulate, $7-25 \times 5-11 \mathrm{~mm}$, dark green above, purple below, subglabrose; cauline leaves narrowly elliptical, subsessile, glabrous, elliptical to lanceolate. Flower in elongating lax raceme. Pedicels erect-patent, slender, $5-15 \mathrm{~mm}$, as long as or longer than leaf-like bracts. Calyx lobes 5-9 mm, linear to linear-spathulate, obtuse, usually patents. Corolla white, suffused with violet on the upper lip, $8.5-10.5 \mathrm{~mm}$; spur tapering, 2-3 mm, subacute. Capsule spherical, $4.5-6 \mathrm{~mm}$ long, shorter than calyx teeth. Seeds ovoid-ellipsoid, $0.65-0.70 \times$ 0.45-0.50 mm, dark brown to black, with prominent longitudinal crest, discontinuous, clearly echinate, testa of the intercostal spaces covered by papilla (Figs. 2,3).

Flowering and fruiting time: May-June.

Habitat: Recently burned Pinus brutia forest from 100 to $200 \mathrm{~m}$ altitude.

Examined specimens: Turkey: C1 Muğla: Ören, between Çamlica and Kumluca villages, recently burned Pinus brutia forest, $150 \mathrm{~m}, 37^{\circ} 03^{\prime} 28.50^{\prime \prime} \mathrm{N}, 27^{\circ} 57^{\prime} 34.26^{\prime \prime} \mathrm{E}, 09$ May 2014, G. Zare \& G. Ergan, GZ963 (HUB!)

Greece: Arkadhia, Ep. Mandinias, NW Artemisi, Acker, Krautflurent, 600 m, 370 $41^{\prime} 04^{\prime \prime}$ N, 22 $21^{\circ} 41^{\prime \prime}$ E, Jaunery 2007, FG 27, No 93.138 (B!)

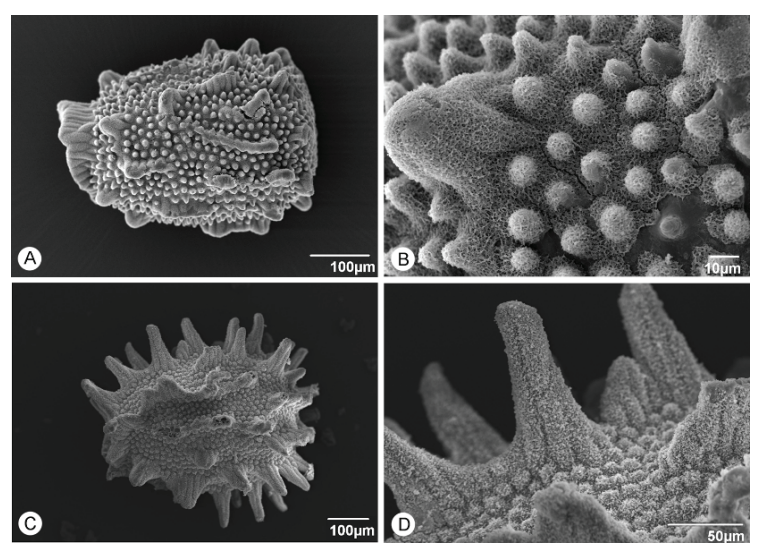

Fig. 2. Comparison of seed ornamentations by SEM. A, B) Chaenorhinum gerense (GZ1093); C, D) C. rubrifolium (GZ963). 


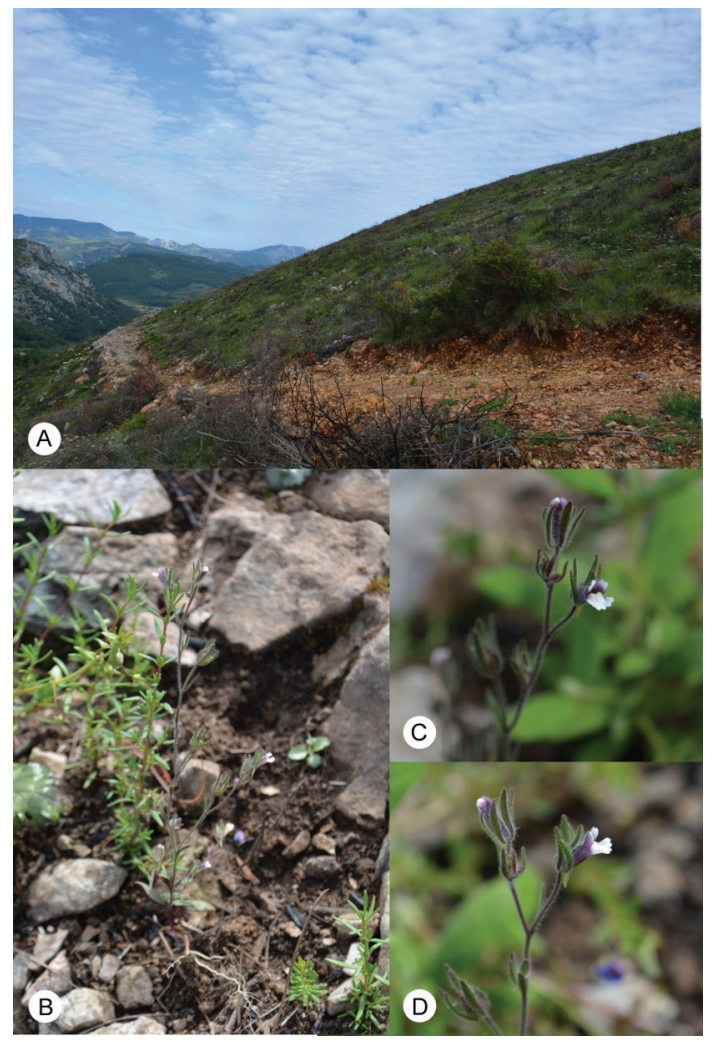

Fig. 3. Chaenorhinum rubrifolium: A) habitat; B) a general appearance; C, D) flowers (GZ963).

Cyprus: Aradippou, SW of village, eastern side of motorway S of Kalo Chorio/Aradippou exit open gypsum slopes, c. 100 m, 3456'32" N 33³3'49" E, 07 May 2009, R. Hand \& C.S. Christodoulou (B!)

Morocco: Prov. Taza, S of road Azrou-Fes, lake Dayat Aoua, N-side; 1480 m, 23 June 1996, A.chhal el Kadmiri \& E. Vitek 96-0889 (W!)

Italy: Dorgali, Sudhang des Mte. Bardia oberh. Cala Gonone. Ca. 450 m, 20 April 1966, H. Merxmuller \& F. Oberwinkler 21129 (MSB!)

Spain: Almeria, Sierra Alhamilla, cerca del Cortijo 1000 m, 14 April 1921, E Gros 19/27 (W!, BC!); Formentera, Cap de Berberia, ca. $2 \mathrm{~km}$ sudl. Von Can Fita, Bodenaushubflache am Wege, 8 Jun 1972, H. Kuhbier U. G. Finschow (MSB!); Aranjuez (Madrid), 15 May 1945, Rivas Goday et Monasterio (MSB!); LA RIOJA, Leza de Rio Leza. 30TWM4988, 500 m., 28 June 1985, A.S. Rodriguez, (MSB!, BC!); Cadiz: Sierra del Pinar, ad 1550 m., 1.Julay.1925, P.Font, I. Quer \& E. Gros, (MSB!, BC!); Toledo: Yepes, 30SVK4717, 700 m., 11 June 1984, Amich Y Ehas. (BC!); Yebra de Basa, Mont Serraton, au nord du village, 970 m, 30TYN2308, 28 May 1988, P. Montserrat n JACA 112388 (MSB!, BC!)

General distribution: Algeria, Baleares, Greece, France, Italy, Morocco, Spain, Tunisia and Turkey.

Chaenorhinum rubrifolium is a species with a complex taxonomy consisting of many subspecies, varieties and forms depending upon the treatment of different authors (Fernandes 1971, Speta 1980, Sutton 1988, Benedí-González 1991). These taxonomic problems are mainly based on the distribution area of these taxa and the lack of sufficient collections of materials belonging to this species. In fact, these species are relatively rare despite their wide range from SW Europe and NW Africa to SW Asia (Speta 1980, Sutton 1988, Benedí-González 1991). Our research indicated that seeds of this species have a high-level of dormancy, and they germinate only when some fire-related germination cues are applied (Tavşanoğlu et al. 2017). This germination behaviour of this annual species can explain why it is scarce, and can be found in recently burned Mediterranean sites (Céspedes et al. 2014, Tavşanoğlu et al. 2017). Fernandes (1971) defined three subspecies and two forms for European C. rubrifolium, and following his treatment, Sutton (1988) divided the species into four subspecies: subsp. rubrifolium, subsp. formenterae (Gand.) R. Fernandes (1971:227), subsp. raveyi (Boiss.) R. Fernandes (1971:227) and subsp. gerense (Stapf) D.A.Sutton (1988:114), while some authors have treated all these subspecies as separate species (Benedí and Güemes, 2009).

Davis (1978b) in his account on Turkish Chaenorhinum species listed five species of the genus and he did not include C. rubrifolium. In the Flora of Turkey and East Aegean Islands (Davis 1978a), later, he reported this species from two closely located sites in SE Anatolia based on his collections (Mardin, coll. numb. 28577, coll. numb. 28529 and Cizre, coll. numb. 42705). Davis (1978a) mentioned differences in seed characteristics and non-persistent basal rosette leaves at the flowering time of these samples with West Mediterranean materials but treated these samples as C. rubrifolium. We assume that he evaluated the differences in these specimens as intraspecific variation and did not believe that these characteristics were sufficient for these taxa to be considered separate species. Sutton (1988), during the revision of the genus identified these materials as $C$. rubrifolium subsp. gerense. In the more recently published Flora Iranica by Podlech and Iranshahr (2015), the authors followed the Sutton classification and evaluated this taxon as C. rubrifolium subsp. gerense. Our detailed work on SE Anatolian samples revealed that the indumentum, branching pattern and long calyx teeth of C. gerense resemble those of C. rubrifolium, but it is remarkably different from this species by the small, cream corolla with red blotch, ascending or patent pedicels in fruit, calyx teeth two times longer than the capsule and triangular or rectangular with blunt seed ornamentation type (Tab. 1, Figs. 1-3). Considering all the above, we confirmed the Sutton decision about materials collected from SE Anatolia by Davis, but we believe these specimens should be treated as a separate species, C. gerense. Consequently, these two species have increased the species number of Chaenorhinum in Turkey to nine, in which five are endemic. In any case, further research is still needed to clarify the relationships among Chaenorhinum taxa at interand intra-species levels. 
Table 1. Morphological comparison of Chaenorhinum gerense with C. rubrifolium.

\begin{tabular}{lll}
\hline Characters & C. rubrifolium & C. gerense \\
\hline Height $(\mathrm{cm})$ & $4-22$ & $2.5-12(25)$ \\
Basal leaves & Leaves subsessile, ovate to ovate-oblong & Leaves petiolate, elliptic-ovate \\
Basal leave size $(\mathrm{mm})$ & $7-25 \times 5-11$ & $8-12 \times 3-4$ \\
Pedicels $(\mathrm{mm})$ & $5-15$, erect & $3-10$, ascending \\
Flower & Erect & Patent \\
Corolla colour & White with violet upper lip & Cream with red batch in upper lip \\
Corolla size $(\mathrm{mm})$ & $8.5-10.5$ & $5-7(9)$ \\
Spur $(\mathrm{mm})$ & $2-3$ & $1.5-2$ \\
Calyx teeth $(\mathrm{mm})$ & $6-8$ unequal & $5-7$ unequal \\
Capsule $(\mathrm{mm})$ & slightly longer than capsule & $2 \times$ longer than capsule \\
Seed ornamentation & $4.5-6$ & $2-3$ \\
Seed size $(\mathrm{mm})$ & Crest echinate (spiny) & Crest triangular or rectangular with blunt and obtuse apex \\
\hline
\end{tabular}

\section{Identification key to the genus Chaenorhinum in Turkey}

1a. Flowers subsessile; calyx lobes 8-15 mm; corolla 14-20 mm (excl. spur); seeds cuneate-oblong, appearing pitted between main ribs

1b. Flowers conspicuously pedicellate; calyxlobes $2-6 \mathrm{~mm}$; corolla 6-10 $\mathrm{mm}$ (excl.spur); seeds ovoid-ellipsoid to broadlyoblong, not appearing pitted.

2a. Corolla spur $2-3 \mathrm{~mm}$

.huber-morathii

2b. Corolla spur $9-12 \mathrm{~mm}$

3a. Capsule longer than calyx lobes; seeds $0.5-1 \mathrm{~mm}$, seeds with distinctly broad crest; plant not chasmophytic

3b. Capsule shorter or as long as calyx lobes, spherical; seeds $0 \cdot 3-0.7 \mathrm{~mm}$, echinate or with discontinues crest; plants chasmophytic

4a. Seeds $0.5-0.7 \mathrm{~mm}$; capsule 3-5 $\mathrm{mm}$, slightly longer than broad; branches usually flexuous minus

4b. Seeds $0.8-1 \mathrm{~mm}$; capsule longer than $5 \mathrm{~mm}$; spherical; branches \pm straight litorale subsp.pterosporum

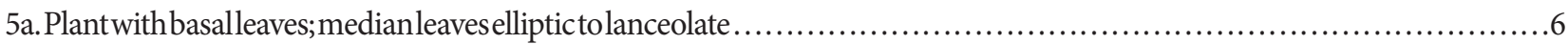

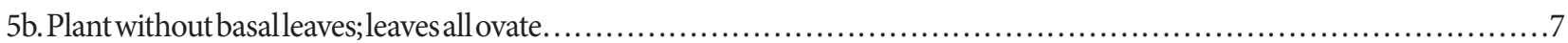

6a. Leaves petiolate; capsule 2-3 $\mathrm{mm}$; seeds $0.3-0.5 \mathrm{~mm}$, cresta discontinues, triangular or rectangular with blunt apex gerense

6b. Leaves subsessile; capsule $4.5-6 \mathrm{~mm}$; seeds $0.6-0.7 \mathrm{~mm}$, cresta echinate. rubrifolium

7a. Calyx lobes 4-5 mm; seeds shallowly ribbed semispeluncarum 7b. Calyx lobes $2-3 \mathrm{~mm}$; seeds distinctly ribbed. .yildirimlii 8a. Inflorescence secund; pedicels recurved in fruit; seeds $0.5-0.6 \mathrm{~mm}$. cryptarum

8 b. Inflorescence multilateral, pedicels erect in fruit; seeds $0.7-0.9 \mathrm{~mm}$. .8

\section{Acknowledgements}

The Rufford Foundation [RSG 13663-1] financially supported the field work and G. Ergan. G. Zare thanks to the Scientific and Technical Research Council of Turkey (TÜBİTAK-BİDEB 2216) for their financial support.

\section{References}

Benedí, C., Güemes, J., 2009: Chaenorhinum. In: C. Benedi, E. Rico, J. Güemes, Al- berto Herrero (eds.), Flora Iberica. Plantas vasculares de la Península Ibérica e Islas Baleares. Vol. XIII, Plantaginaceae-Scrophulariaceae, 167-198. Real Jardín Botánico, Madrid, Spain.

Benedí-González, C., 1991: Taxonomy of Chaenorhinum rubrifolium aggr. (Scrophulariaceae) in western Mediterranean area. Collectanea Botanica (Barcelona) 20, 35-77.
Céspedes, B., Torres, I., Pérez, B., Luna, B., Moreno, J. M., 2014: Burning season does not affect post-fire regeneration but fire alters the balance of the dominant species in a seeder-dominated Mediterranean shrubland. Applied Vegetation Science $17,711-725$.

Davis, P. H., 1978a: Chaenorhinum. In: Davis, P. H. (ed.), Flora of Turkey and the east Aegean Islands. Vol. 6, 650-654. Edinburgh University Press. 
Davis, P. H., 1978b: Chaenorhinum. In: Davis, P. H. (ed.), Materials for a flora of Turkey XXXV: Primulaceae and Scrophulariaceae, 36, 1-22. Notes from the Royal Botanic Garden, Edinburgh.

De Candolle, A. P., 1815: Flore Francaise. Vol. 5. Desray, Paris.

Endlicher, S., 1839: Genera plantarum secundum ordines naturales disposita part 9. Vienna.

Fernandes, R. B., 1971: Notes taxonomiques sur le genre Chaenorrhinum (DC.) Reichenb. In: V. H. Heywood (ed.), Flora Europaea. Notulae Systematicae ad Hora Europaeam Spectantes $n$. 9. Botanical Journal Linnean Society 64, 215-229.

Fourreau, M., 1869: Catalogue des plantes du cours du Rohne, Annales de la Societe Linneenne de Lyon 17, 89-201.

Plaza, L., Fernandez, I., Juan, R., Pastor, J., Pujadas, A., 2004: Micromorphological studies on seeds of Orobanche species from the Iberian Peninsula and the Balearic Islands, and their systematic signi cance. Annals of Botany 94, 167-178.

Podlech, D., Iranshahr, M., 2015: Chaenorhinum. In: Rechinger, K.H. (ed.), Flora Iranica. Vol. 180, 4-11. Naturhistorischen Museums Wien.

Reichenbach, H.G.L. 1828: Conspectus regni vegetabilis. Cnobloch, Leipzig.
Speta, F., 1980: Die Gattungen Chaenorhinum (DC.) Reichenb. und Microrrhinum (Endl.) Fourr. Im Östlichen Teil ihrer areale (Balkan bis Indien). Stapfia 7, 1-72.

Stapf, O., 1906: Plantarum Novarum in Herbario Horti Regii Conservatarum. Decades XL, XLI. Bulletin of Miscellaneous Information Kew 3, 71-78.

Sutton, D. A., 1988: A revision of the tribe Antirrhineae. Oxford University Press. London \& Oxford.

Tavşanoğlu, Ç., Ergan, G., Çatav, Ş.S., Zare, G., Küçükakyüz, K., Özüdoğru, B., 2017: Multiple fire-related cues stimulate germination in Chaenorhinum rubrifolium (Plantaginaceae), a rare annual in the Mediterranean Basin. Seed Science Research 27, 26-38.

Thiers, B., 2016+ [continuously updated]: Index Herbariorum: A global directory of public herbaria and associated staff. New York Botanical Garden's Virtual Herbarium. Retrieved November, 2016 from http://sweetgum.nybg.org/science/ih/.

Yıldırım, H., Tan, K., Şenol, S. G., Pirhan, A. F., 2010: Chaenorhinum semispeluncarum sp. nov. and C. yildirimlii sp. nov. (Scrophulariaceae) from east Anatolia, Turkey. Nordic Journal of Botany 28, 457-464. 